\title{
Evaluation of the Impact of the Defense Waste Processing Facility (DWPF) Laboratory Germanium Oxide Use on Recycle Transfers to the H-Tank Farm
}

\author{
C.M. Jantzen
}

J.E. Laurinat

August 2011

Savannah River National Laboratory

Savannah River Nuclear Solutions, LLC

Aiken, SC 29808

Prepared for the U.S. Department of Energy under contract number DE-AC09-08SR22470.

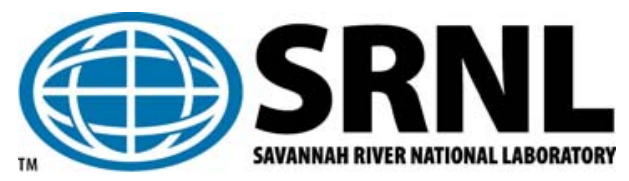


SRNL-STI-2011-00389

Revision 0

\section{DISCLAIMER}

This work was prepared under an agreement with and funded by the U.S. Government. Neither the U.S. Government or its employees, nor any of its contractors, subcontractors or their employees, makes any express or implied:

1. warranty or assumes any legal liability for the accuracy, completeness, or for the use or results of such use of any information, product, or process disclosed; or

2. representation that such use or results of such use would not infringe privately owned rights; or

3. endorsement or recommendation of any specifically identified commercial product, process, or service.

Any views and opinions of authors expressed in this work do not necessarily state or reflect those of the United States Government, or its contractors, or subcontractors.

\section{Printed in the United States of America \\ Prepared for \\ U.S. Department of Energy}


Keywords: melter recycle, germanium, evaporators, precipitation

Retention: Permanent

\title{
Evaluation of the Impact of the Defense Waste Processing Facility (DWPF) Laboratory Germanium Oxide Use on Recycle Transfers to the H-Tank Farm
}

\author{
C.M. Jantzen \\ J.E. Laurinat
}

August 2011

Savannah River National Laboratory

Savannah River Nuclear Solutions, LLC

Aiken, SC 29808

Prepared for the U.S. Department of Energy under contract number DE-AC09-08SR22470.

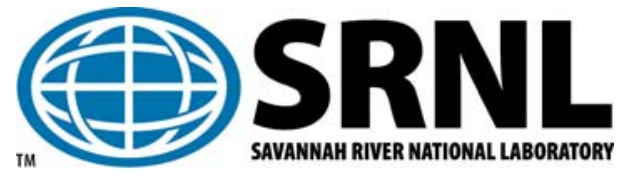




\section{REVIEWS AND APPROVALS}

AUTHORS:

C.M. Jantzen, Process Technology Programs

Date

J.E. Laurinat, Process Modeling \& Computational Chemistry

Date

TECHNICAL REVIEW:

M.E. Stone, Process Technology Programs

Date

APPROVAL:

C.C. Herman, Manager

Date

Process Technology Programs

S.L. Marra, Manager

Date

Environmental \& Chemical Process Technology Research Programs

J.E. Occhipinti, Manager

Date

Waste Solidification Engineering 
SRNL-STI-2011-00389

Revision 0

\section{EXECUTIVE SUMMARY}

When processing High Level Waste (HLW) glass, the Defense Waste Processing Facility (DWPF) cannot wait until the melt or waste glass has been made to assess its acceptability, since by then no further changes to the glass composition and acceptability are possible. Therefore, the acceptability decision is made on the upstream feed stream, rather than on the downstream melt or glass product. This strategy is known as "feed forward statistical process control." The DWPF depends on chemical analysis of the feed streams from the Sludge Receipt and Adjustment Tank (SRAT) and the Slurry Mix Evaporator (SME) where the frit plus adjusted sludge from the SRAT are mixed. The SME is the last vessel in which any chemical adjustments or frit additions can be made. Once the analyses of the SME product are deemed acceptable, the SME product is transferred to the Melter Feed Tank (MFT) and onto the melter.

The SRAT and SME analyses have been analyzed by the DWPF laboratory using a "Cold Chemical" method but this dissolution did not adequately dissolve all the elemental components. A new dissolution method which fuses the SRAT or SME product with cesium nitrate $\left(\mathrm{CsNO}_{3}\right)$, germanium (IV) oxide $\left(\mathrm{GeO}_{2}\right)$ and cesium carbonate $\left(\mathrm{Cs}_{2} \mathrm{CO}_{3}\right)$ into a cesium germanate glass at $1050^{\circ} \mathrm{C}$ in platinum crucibles has been developed. Once the germanium glass is formed in that fusion, it is readily dissolved by concentrated nitric acid (about $1 \mathrm{M}$ ) to solubilize all the elements in the SRAT and/or SME product for elemental analysis.

When the chemical analyses are completed the acidic cesium-germanate solution is transferred from the DWPF analytic laboratory to the Recycle Collection Tank (RCT) where the $\mathrm{pH}$ is increased to $\sim 12 \mathrm{M}$ to be released back to the tank farm and the $2 \mathrm{H}$ evaporator. Therefore, about $2.5 \mathrm{~kg} / \mathrm{yr}$ of $\mathrm{GeO}_{2} /$ year will be diluted into 1.4 million gallons of recycle. This $2.5 \mathrm{~kg} / \mathrm{yr}$ of $\mathrm{GeO}_{2}$ may increase to $4 \mathrm{~kg} / \mathrm{yr}$ when improvements are implemented to attain an annual canister production goal of 400 canisters. Since no Waste Acceptance Criteria (WAC) exists for germanium in the Tank Farm, the Effluent Treatment Project, or the Saltstone Production Facility, DWPF has requested an evaluation of the fate of the germanium in the caustic environment of the RCT, the $2 \mathrm{H}$ evaporator, and the tank farm.

This report evaluates the effect of the addition of germanium to the tank farm based on

- $\quad$ the large dilution of Ge in the RCT and tank farm

- $\quad$ the solubility of germanium in caustic solutions ( $\mathrm{pH} 12-13)$

- $\quad$ the potential of germanium to precipitate as germanium sodalites in the $2 \mathrm{H}$

Evaporator, and

- the potential of germanium compounds to precipitate in the evaporator feed tank.

This study concludes that the impacts of transferring up to $4 \mathrm{~kg} / \mathrm{yr}$ germanium to the RCT (and subsequently the $2 \mathrm{H}$ evaporator feed tank and the $2 \mathrm{H}$ evaporator) results in $<2 \mathrm{ppm}$ per year (1.834 $\mathrm{mg} / \mathrm{L})$ which is the maximum instantaneous concentration expected from DWPF. This concentration is insignificant as most sodium germanates are soluble at the high $\mathrm{pH}$ of the feed tank and evaporator solutions. Even if sodium aluminosilicates form in the $2 \mathrm{H}$ evaporator, the $\mathrm{Ge}$ will likely substitute for some small amount of the $\mathrm{Si}$ in these structures and will be insignificant.

It is recommended that the DWPF continue with their strategy to add germanium as a laboratory chemical to Attachment 8.2 of the DWPF Waste Compliance Plan (WCP). 


\section{TABLE OF CONTENTS}

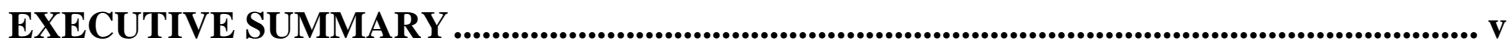

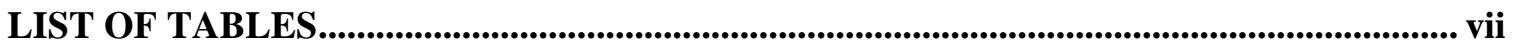

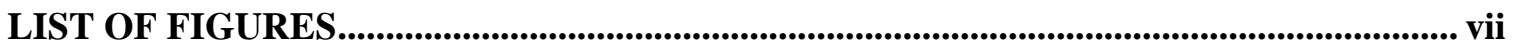

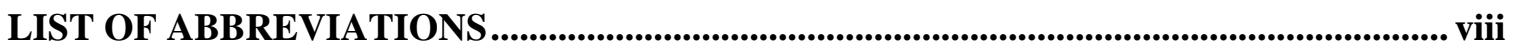

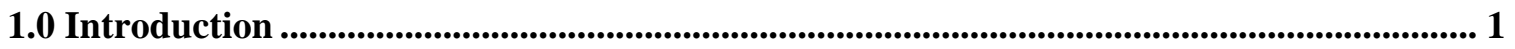

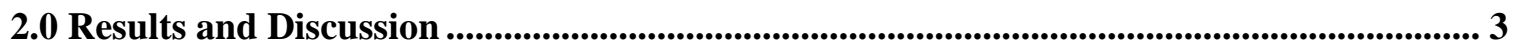

2.1 Dilution of Germanium in RCT Transfers to the Tank Farm .......................................... 3

2.2 Solubility of Germanium in Caustic Solution ..................................................................... 3

2.3 Precipitation of Germanium Sodalites in the $2 \mathrm{H}$ Evaporator ........................................ 7

2.4 Precipitation of Germanium Solids in the Evaporator Storage or Feed Tanks ............. 9

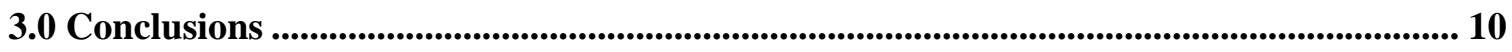

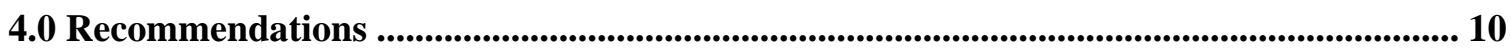

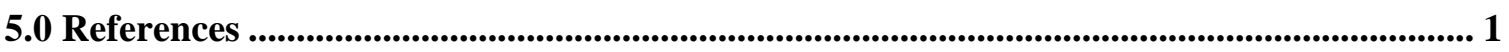


SRNL-STI-2011-00389

Revision 0

\section{LIST OF TABLES}

Table I. Structurally Related Zeolite-A, Sodalite,and Cancrinite Group Phases............................ 9

\section{LIST OF FIGURES}

Figure 1. DWPF flowsheet showing sludge receipt from the tank farm into the SRAT followed by frit addition in the SME and qualification of the SME product (sludge and frit) via analyses and processing through PCCS before the acceptable feed can be transferred to

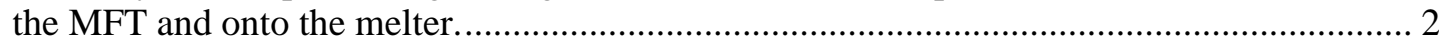

Figure 2. Comparison of Germanate Solubilities Measured by Gayer and Zajicek ${ }^{10}$ with Silicate Solubilities Calculated by OLI. (Note: Gayer and Zajicek did not measure the $\mathrm{pH}$ for the two highest two solubilities. These $\mathrm{pH}$ 's are estimated from the $\mathrm{NaOH}$ concentration of the starting solution, assuming complete dissociation of the $\mathrm{NaOH}$.) 6

Figure 3. Predicted Solubility Ranges for Germanium in Basic Solutions. ................................. 7 


\section{LIST OF ABBREVIATIONS}

$\begin{array}{ll}\text { DWPF } & \text { Defense Waste Processing Facility } \\ \text { HLW } & \text { High Level Waste } \\ \text { MFT } & \text { Melter Feed Tank } \\ \text { PCCS } & \text { Product Composition Control System } \\ \text { PDF } & \text { Powder Diffraction File } \\ \text { RCT } & \text { Recycle Collection Tank } \\ \text { SME } & \text { Slurry Mix Evaporator } \\ \text { SPC } & \text { Statistical Process Control } \\ \text { SQC } & \text { Statistical Quality Control } \\ \text { SRAT } & \text { Sludge Receipt and Adjustment Tank } \\ \text { SRNL } & \text { Savannah River National Laboratory } \\ \text { SRR } & \text { Savannah River Remediation } \\ \text { TAR } & \text { Technical Assistance Request } \\ \text { WCP } & \text { Waste Compliance Plan }\end{array}$




\subsection{Introduction}

When processing High Level Waste (HLW) glass, a production facility such as the Defense Waste Processing Facility (DWPF) cannot wait until the melt or waste glass has been made to assess its acceptability, since by then no further changes to the glass composition and acceptability are possible. Therefore, the acceptability decision is made on the upstream feed stream, rather than on the downstream melt or glass product. That is, it is "feed forward" statistical process control (SPC) ${ }^{\dagger}$ rather than statistical quality control (SQC) ${ }^{\dagger \dagger}$ In SPC, the feed composition to the melter is controlled prior to vitrification. In SQC, the glass product is sampled after it is vitrified. With feed forward process control, individual property models are used to transform constraints on the melt and product properties into constraints on the feed composition, e.g. the melter is treated as a "black box" and the glass quality in the canister is controlled at 95\% confidence from the incoming feed composition, this SPC control strategy is known as the Product Composition Control System (PCCS). ${ }^{1,2}$

For the DWPF, the PCCS depends on chemical analysis of the feed streams from the Sludge Receipt and Adjustment Tank (SRAT) and the Slurry Mix Evaporator (SME) where the frit plus adjusted sludge from the SRAT is mixed (Figure 1). The SME is the last vessel in which any chemical additions or frit additions can be made to adjust the DWPF feed composition. Once the analyses of the SME product are deemed acceptable by PCCS, the SME product is transferred to the Melter Feed Tank (MFT) and onto the melter (Figure 1).

The SRAT and SME analyses have routinely been analyzed by the DWPF laboratory using a "Cold Chemical" method but this dissolution in preparation for analysis did not adequately dissolve all the elemental components. A new dissolution method which fuses the SRAT or SME product with cesium nitrate $\left(\mathrm{CsNO}_{3}\right)$, germanium (IV) oxide $\left(\mathrm{GeO}_{2}\right)$ and cesium carbonate $\left(\mathrm{Cs}_{2} \mathrm{CO}_{3}\right)$ into a cesium germanate glass at $1050^{\circ} \mathrm{C}$ in platinum crucibles has been developed. ${ }^{3,4}$ Once the germanium glass is formed by fusion, it is readily dissolved by concentrated nitric acid (about 1M) to solubilize all the elements in the SRAT and/or SME product for elemental analysis.

When the chemical analyses on the solubilized SRAT and/or SME are completed for PCCS the acidic cesium-germanate dissolution goes from the DWPF analytic laboratory to the Recycle Collection Tank (RCT) where the $\mathrm{pH}$ is increased to $\sim 12 \mathrm{M}$ to be released back to the tank farm and the $2 \mathrm{H}$ evaporator. The DWPF currently generates approximately 1.4 million gallons of RCT recycle per year in 5000 gallon batches ${ }^{3}$ during Sludge-Only operations. Therefore, about 2.5 $\mathrm{kg} / \mathrm{yr}$ of $\mathrm{GeO}_{2}$ will be diluted into 1.4 million gallons of recycle. ${ }^{5}$ This $2.5 \mathrm{~kg} / \mathrm{yr}$ of $\mathrm{GeO}_{2}$ may increase to $4 \mathrm{~kg} / \mathrm{yr}$ when improvements are implemented to attain an annual canister production goal of 400 canisters. Since no Waste Acceptance Criteria (WAC) existed for germanium in the Tank Farm, ${ }^{6}$ the Effluent Treatment Project, ${ }^{7}$ or the Saltstone Production Facility, ${ }^{8}$ DWPF has recently added a $\mathrm{GeO}_{2}$ limit to Attachment 8.2 of the DWPF Waste Compliance Plan (WCP). The upper limit is $1.834 \mathrm{mg} / \mathrm{L}(<2 \mathrm{ppm})$ which is the maximum instantaneous concentration expected from DWPF. The DWPF then requested an evaluation of the fate of this small amount of germanium in the caustic environment of the RCT, the $2 \mathrm{H}$ evaporator, and the tank farm.

The following potential impacts have been either experimentally demonstrated or hypothesized and will be evaluated in this study:

$\dagger \quad$ This controls the Slurry Feed to the Melter prior to vitrification.

i† Which would adjudicate product release by sampling the glass after it's been made. 
- no effect due to the small amount of germanium added to the RCT per year, ${ }^{3}$

- no effect based on an experiment performed by C. Coleman of SRNL that demonstrated that the germanium dissolution/analytic residues would remain soluble up to $\mathrm{pH} 13,{ }^{3}$

- some effect based on potential precipitation as germanium hydroxide, as a germanium sodalite, or due to some carrier effect of the SRAT or SME dissolution products where it could increase the insoluble solids in the RCT stream, ${ }^{3}$

- some effect based on potential precipitation of germanium hydroxide or germanium aluminate sodalites in the evaporator, or

- some effect based on potential for precipitation in the evaporator feed tank.

This report is in response to Technical Assistance Request (TAR) HLW-DWPF-TAR-201100007 (May 13, 2011) to address the following:

- Evaluation of the effect of the addition of germanium to the tank farm based on

- the large dilution of Ge in the RCT and tank farm,

- $\quad$ the solubility of germanium in caustic solutions ( $\mathrm{pH} 12-13$ ),

- the potential of germanium to precipitate as germanium sodalites, and

- $\quad$ the potential of germanium species to precipitate in the evaporator feed tank.

SLUDGE FEED TANK FARM

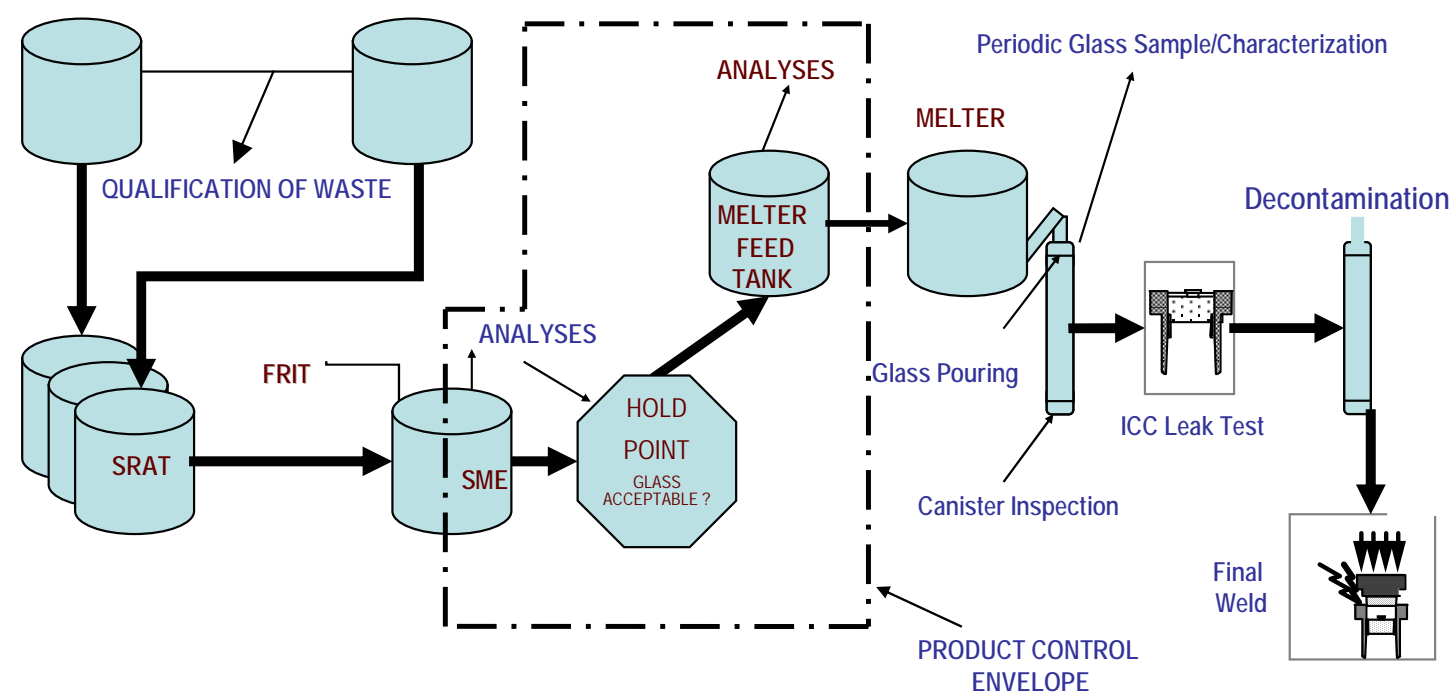

Figure 1. DWPF flowsheet showing sludge receipt from the tank farm into the SRAT followed by frit addition in the SME and qualification of the SME product (sludge and frit) via analyses and processing through PCCS before the acceptable feed can be transferred to the MFT and onto the melter. 
SRNL-STI-2011-00389

Revision 0

\subsection{Results and Discussion}

\subsection{Dilution of Germanium in RCT Transfers to the Tank Farm}

A minimum of $2.5 \mathrm{~kg} / \mathrm{yr}^{3}$ and a maximum of $4 \mathrm{~kg} / \mathrm{yr}^{3}$ of germanium, presumably soluble based on Coleman's experiments ${ }^{3}$ and the solubility of germanium species in caustic discussed in Section 2.2, would be diluted into 1.4 million gallons of RCT recycle per year. ${ }^{5}$ This gives an annual concentration of $0.47-0.754 \mathrm{mg} / \mathrm{L}$ or $\mathrm{ppm}$ of germanium to be added to either Tank 22 (DWPF recycle storage tank and also an alternate $2 \mathrm{H}$ evaporator feed tank), Tank 41 (used for salt dissolution), Tank 38 (2H evaporator drop tank) or Tank 43 (2H evaporator feed tank). Since the 1.4 million gallons of RCT material per year can be sent to any of these tanks and eventually fed or recylced to the evaporator feed tank (Tank 43) in 5000 gallon batches, ${ }^{3}$ the upper bound was calculated ${ }^{3}$ to be $1.834 \mathrm{mg} / \mathrm{L}$. Further dilution of this $1.834 \mathrm{ppm}$ will occur with other incoming feed sources to Tanks 22, 38, 41 and 43 and eventually a 60\% evaporation of this material will occur on each pass of the feed tank supernate to the drop tank. The relative magnitude of the dilution from other incoming feed sources into Tanks 22, 38, 41 and 43 vs. concentration by the $2 \mathrm{H}$ evaporator cannot be quantified. However, it would require more than 100 fold increase in concentration to exceed $200 \mathrm{ppm}$. It is doubtful that this amount of concentration could occur, but even 200 ppm still a very small concentration of germanium recognizing that it can substitute for $\mathrm{Si}$ in the sludge or supernates in the above mentioned tanks.

\subsection{Solubility of Germanium in Caustic Solution}

DWPF anticipates a transfer of a maximum of $4.0 \mathrm{~kg} / \mathrm{yr}$ of germanium per year. To evaluate the possibility of precipitation in either the RCT or the waste tanks, DWPF has requested an estimate of the solubility of germanium in basic solutions.

Baes and Mesmer ${ }^{9}$ discuss germanium chemistry in aqueous solutions. According to their discussion, germanium is normally present in the +4 valence state in aqueous solution and exhibits behavior similar to that of silicon. In neutral or slightly basic solution, the predominant soluble species is the neutral oxide, $\mathrm{GeO}_{2}$ (or $\mathrm{Ge}(\mathrm{OH})_{4}$ in the hydrolyzed form). As the $\mathrm{pH}$ increases to approximately 11 , the monovalent species $\mathrm{HGeO}_{3}{ }^{-}$(or $\mathrm{GeO}(\mathrm{OH})_{3}{ }^{-}$) predominates, and above a pH of 12 to 13 , the divalent species $\mathrm{GeO}_{3}{ }^{2-}$ (or $\mathrm{GeO}_{2}(\mathrm{OH})_{2}{ }^{2-}$ ) becomes prevalent. Baes and Mesmer ${ }^{9}$ noted a slightly greater tendency for the formation of $\mathrm{GeO}_{2}(\mathrm{OH})_{2}{ }^{2-}$ than for $\mathrm{SiO}_{2}(\mathrm{OH})_{2}{ }^{2-}$. The equilibrium equations for the ionic speciation of germanium, in terms of the nonhydrolyzed species, are

$$
\mathrm{GeO}_{2}(\mathrm{aq})+\mathrm{NaOH} \leftrightarrow \mathrm{NaHGeO}_{3}
$$

and

$$
\mathrm{NaHGeO}_{3}+\mathrm{NaOH} \leftrightarrow \mathrm{Na}_{2} \mathrm{GeO}_{3}+\mathrm{H}_{2} \mathrm{O}
$$

A literature search found only one set of reliable measurements of germanium solubility in basic solutions, that of Gayer and Zajicek. ${ }^{10}$ Gayer and Zajicek measured germanium solubilities at $25{ }^{\circ} \mathrm{C}$ over a $\mathrm{pH}$ range of approximately 8.5 to 14.5 by contacting aqueous $\mathrm{NaOH}$ solutions with solid $\mathrm{GeO}_{2}$ under an inert atmosphere. The test solutions were allowed to equilibrate for two 
weeks in sealed flasks. At the end of this time, the flasks were opened and the soluble germanium concentration and the $\mathrm{pH}$ were measured.

Gayer and Zajicek ${ }^{10}$ correlated their results with two equilibrium constants, one that relates the activities of the metagermanate and hydroxyl ions $\left(\mathrm{HGeO}_{3}{ }^{-}\right.$and $\left.\mathrm{OH}^{-}\right)$and a second that gives the solubility of the neutral species $\mathrm{GeO}_{2}$ :

$$
\mathrm{K}_{1}=\frac{\mathrm{a}_{\mathrm{HGeO}_{3}}{ }^{-}}{\mathrm{a}_{\mathrm{OH}^{-}}} \cong \frac{\left[\mathrm{HGeO}_{3}^{-}\right]}{\left[\mathrm{OH}^{-}\right]}=4.40
$$

and

$$
\mathrm{K}_{2}=\mathrm{a}_{\mathrm{GeO}_{2}} \cong\left[\mathrm{GeO}_{2}\right]=0.016
$$

As indicated by these equilibrium expressions, the activities can be estimated in terms of the ionic concentrations, if it is assumed that: 1) the activity coefficients for $\mathrm{HGeO}_{3}{ }^{-}$and $\mathrm{OH}^{-}$are approximately equal: and 2) that the activity coefficient of $\mathrm{GeO}_{2}$ is one.

Gayer and Zajicek ${ }^{10}$ do not provide a correlation for the solubility in the higher $\mathrm{pH}$ range, where the concentration of the divalent species $\mathrm{GeO}_{3}{ }^{2-}$ becomes significant, but they cite previous work by Pugh, ${ }^{11}$ who, based on electrochemical measurements, estimated the hydrolysis equilibrium constant for $\mathrm{GeO}_{3}{ }^{2-}$ as

$$
\mathrm{K}_{\mathrm{h}}=\frac{\left[\mathrm{NaHGeO}_{3}\right][\mathrm{NaOH}]}{\left[\mathrm{Na}_{2} \mathrm{GeO}_{3}\right]}=0.054
$$

Typically, germanium is not included in the standard thermodynamic equilibrium databases for aqueous solutions. However, a comparison can be made between the germanium solubilities measured by Gayer and Zajicek and calculated silicon solubilities. Figure 2 compares the measurements of Gayer and Zajicek with silicon solubilities calculated by the OLI Stream Analyzer ${ }^{\circledR}$, using the same solution composition, with silicon substituted for germanium on a molar basis. For $\mathrm{pH}$ below approximately 11, the OLI calculations give silicon solubilities that approximately equal the measured germanium solubilities. Above $\mathrm{pH} 11$, the calculated silicon solubilities exceed the measured germanium solubilities. However, when the concentrations of soluble $\mathrm{Na}_{2} \mathrm{Si}_{2} \mathrm{O}_{3}$ and $\mathrm{Si}_{2} \mathrm{O}_{3}{ }^{2-}$ are subtracted from the total calculated silicon solubility, the OLI calculations for soluble silicon over this $\mathrm{pH}$ range again nearly match the measured germanium solubilities. This may indicate that Gayer and Zajicek actually measured the germanium solubility for solution in contact with solid $\mathrm{GeO}_{2}$, which might be lower than the ultimate solubility for solutions in contact with $\mathrm{Na}_{2} \mathrm{GeO}_{3}$.

The $\mathrm{pH}$ levels calculated by OLI do not agree with the measured $\mathrm{pH}$, except for a narrow range near $\mathrm{pH} 12$, as Figure 2 shows. Below $\mathrm{pH} 12$, the calculated $\mathrm{pH}$ significantly exceeds the measured $\mathrm{pH}$. This discrepancy might be attributed to the presence of absorbed $\mathrm{CO}_{2}$ in the measured samples. Dissolved $\mathrm{CO}_{2}$ would lower the $\mathrm{pH}$ by coordinating with $\mathrm{Na}^{+}$ions that would otherwise make the solution more caustic. The calculated and measured $\mathrm{pH}$ levels begin to deviate at a germanium/silicon solubility that approximately equals the dissolved $\mathrm{CO}_{2}$

${ }^{\circledR}$ OLI Stream Analyzer is a registered trademark of OLI Systems, Inc., of Morris Plains, New Jersey. 
concentration at saturation, which, according to OLI Stream Analyzer, is $0.0325 \mathrm{M}$. It also may be noted that the measured germanium concentration is nearly equal to the starting $\mathrm{NaOH}$ concentration, at low solubilities. These observations are consistent with a reaction sequence where $\mathrm{CO}_{2}$ absorbed at the solution surface, as the bicarbonate ion $\mathrm{HCO}_{3}{ }^{-}$buffers $\mathrm{Na}^{+}$from the dissolution of germanium. The reason for the difference between the measured and calculated $\mathrm{pH}$ at higher $\mathrm{pH}$ levels is not readily apparent.

The germanate solubility measurements of Gayer and Zajicek also can be compared with measured silicate solubilities. Silicate solubilities measured by $\mathrm{Iler}^{12}$ in slightly basic solutions considerable exceed both the corresponding measured germanate solubilities and silicate solubilities predicted by OLI, as Figure 2 illustrates. The OLI predictions are based on measurements of the solubility of sodium metasilicate hydrates $\left(\mathrm{Na}_{2} \mathrm{SiO}_{3} \cdot \mathrm{xH}_{2} \mathrm{O}\right)$ (Baker and $\left.\mathrm{Jui}^{13}\right)$. The solubility of the metasilicate hydrate at $25{ }^{\circ} \mathrm{C}$ is in approximate agreement with the OLI prediction, as may be seen in Figure 2. It is assumed that the OLI predictions at lower $\mathrm{pH}$ also are valid, since they tie into the measured metasilicate solubility; this implies that the Iler measurements overestimate the solubility at lower $\mathrm{pH}$. Subsequent work by Baker and Jui ${ }^{14}$ indicates that the silicate solubility decreases at higher $\mathrm{pH}$, beyond the equilibrium point for the solubility of the metasilicate (the orange circle in Figure 2). It follows that germanate solubilities also should decrease as the $\mathrm{pH}$ increases above this level.

In view of the preceding discussion, a range of germanium solubilities can be plotted as a function of $\mathrm{pH}$, based on a comparison of measured germanium and calculated silicon solubilities, as shown by Figure 3. At low pH, the lower solubility limit of $0.016 \mathrm{M}(1160 \mathrm{mg} / \mathrm{L}$, or ppm by volume) is for a solution with no absorbed $\mathrm{CO}_{2}$, and the upper solubility limit, which can range up to $0.0325 \mathrm{M}(2360 \mathrm{mg} / \mathrm{L})$, is for a solution saturated with $\mathrm{CO}_{2}$. At higher $\mathrm{pH}$, the lower solubility limit is for solution in contact with solid $\mathrm{GeO}_{2}$, and the upper solubility limit is for solution in contact with solid $\mathrm{Na}_{2} \mathrm{GeO}_{3}$. These estimated solubility limits range from $0.59 \mathrm{M}$ $(42,800 \mathrm{mg} / \mathrm{L})$ to $1.99 \mathrm{M}(144,500 \mathrm{mg} / \mathrm{L})$ at a $\mathrm{pH}$ of 14.5 . 


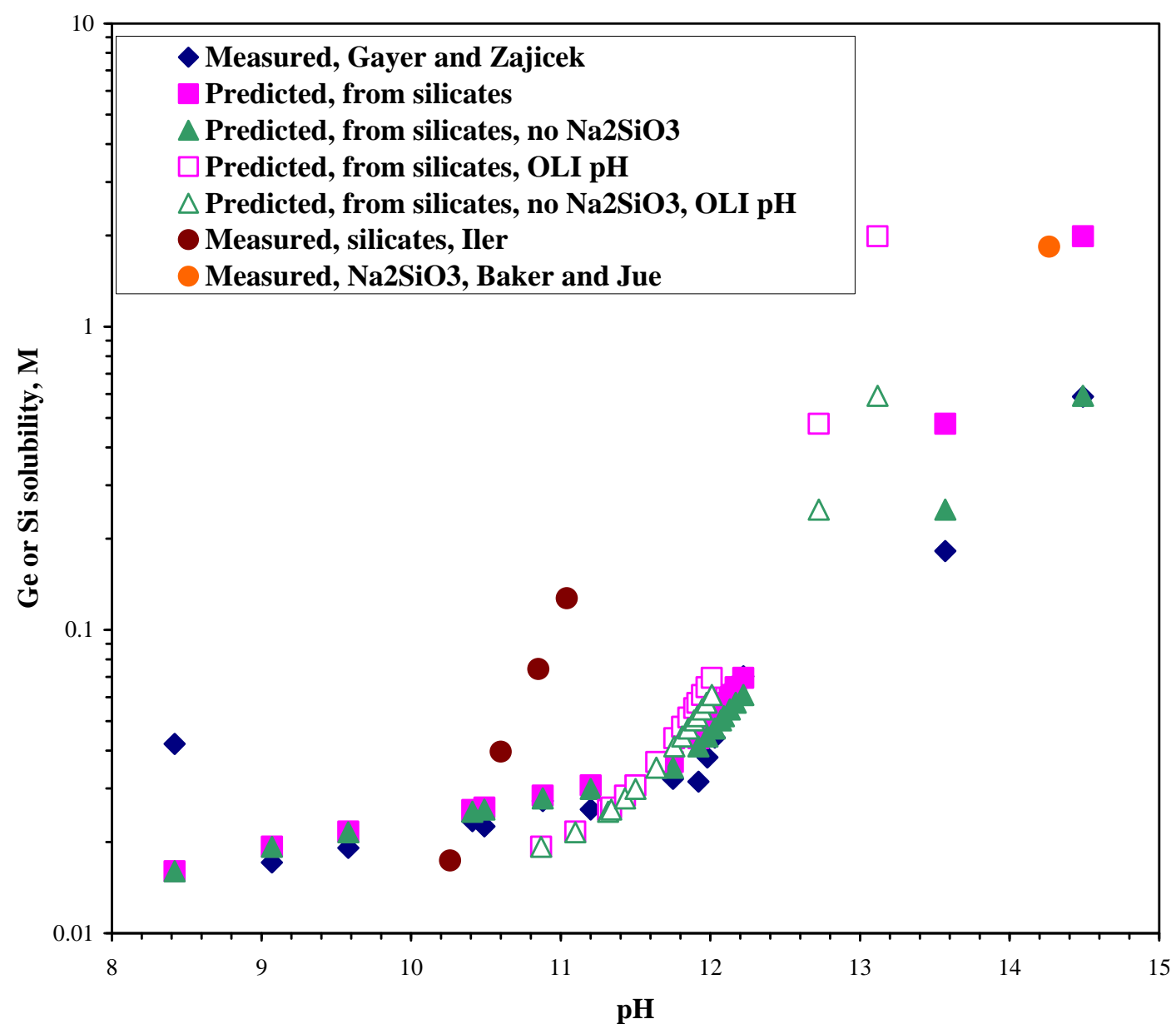

Figure 2. Comparison of germanate solubilities measured by Gayer and Zajicek ${ }^{10}$ with measured silicate solubilities and silicate solubilities calculated by OLI. (Note: Gayer and Zajicek did not measure the $\mathrm{pH}$ for the two highest two solubilities. These pH's are estimated from the $\mathrm{NaOH}$ concentration of the starting solution, assuming complete dissociation of the $\mathrm{NaOH}$. The $\mathrm{pH}$ for the Baker and Jui measurement is estimated by assuming that $\mathrm{Na}_{2} \mathrm{SiO}_{3}$ dissociates to $\mathrm{Na}^{+}$and $\mathrm{HSiO}_{3}{ }^{-}$upon dissolution.) 


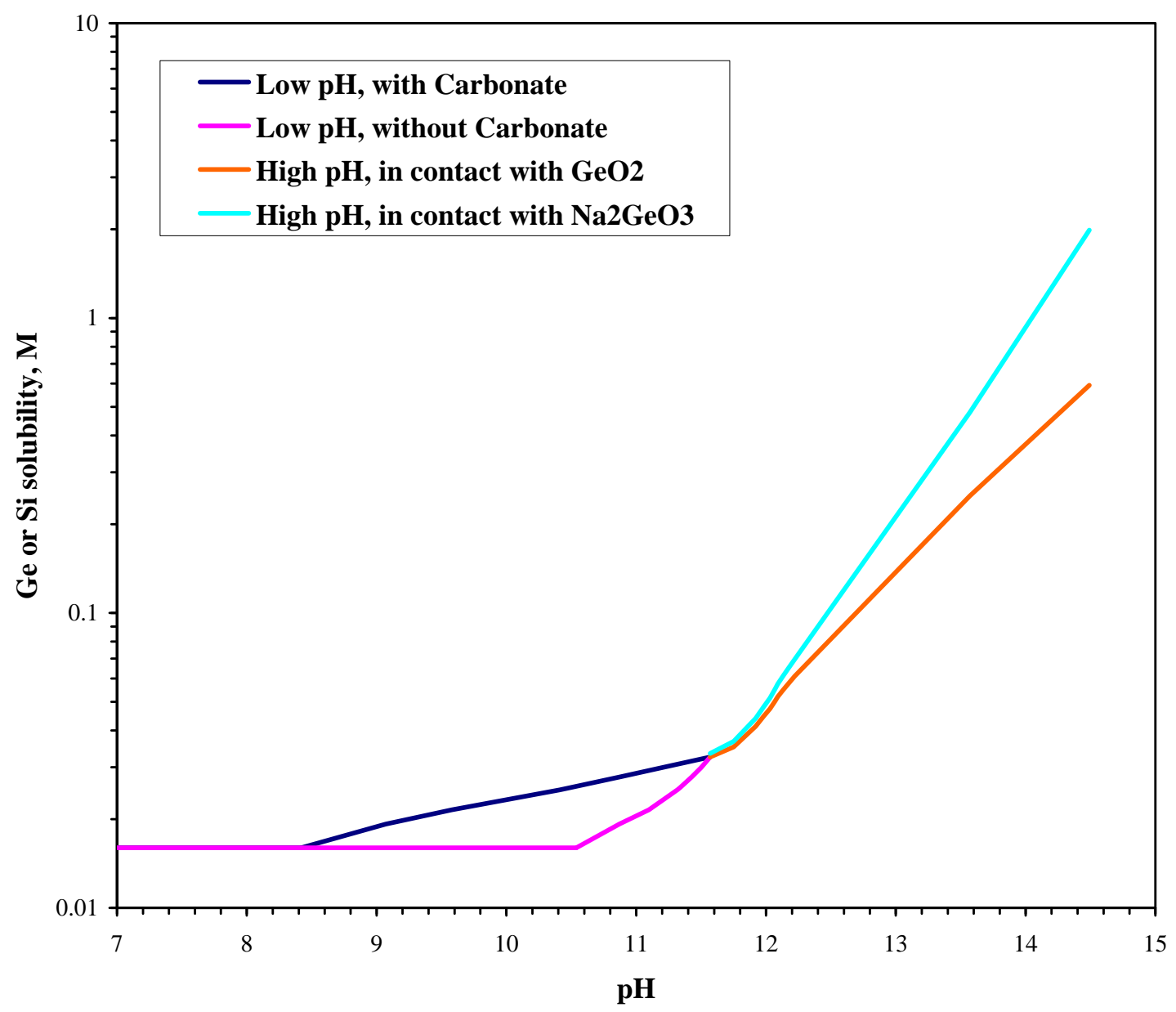

Figure 3. Predicted solubility ranges for germanium in basic solutions.

\subsection{Precipitation of Germanium Sodalites in the $2 \mathrm{H}$ Evaporator}

In aluminosilicate based sodalites, the species known to precipitate in the $2 \mathrm{H}$ evaporator, ${ }^{15}$ germanium can substitute for silicon. The aluminosilicate sodalites that have been found to form in the $2 \mathrm{H}$ evaporator are bolded in Table I. Their alumino-germanate sodalite analogues are also bolded in Table I. Both are known to form from gels at temperatures as low as $100^{\circ} \mathrm{C}$. ${ }^{16}$ The nitrated- and hydroxyl-alumino-germanate sodalites were formed by reacting $\mathrm{Al}_{2} \mathrm{O}_{3}, \mathrm{GeO}_{2}$, water, and $\mathrm{NaNO}_{3}$ and $\mathrm{NaOH}$ at $180^{\circ} \mathrm{C}$ (Powder Diffraction File (PDF) cards \#43-243 and 43-242 give fabrication details that are not given in any standard references) at standard pressure and so it is possible that these phases may form in the $2 \mathrm{H}$ evaporator at $120^{\circ} \mathrm{C}$ although the kinetics would be slower than at $180^{\circ} \mathrm{C}$.

The halide containing germanate sodalites can be formed by melting a glass of a similar composition $^{22}$ and this clearly cannot happen in the evaporator environment. The molar concentration of sodium in the evaporator feed tank (Tank 43) is between 8.6 to $9.4 \mathrm{M}$ at depth (64 to 100 feet) in the tank ${ }^{15}$ and the sodium molarity in the drop tank (Tank 38) ranges from 8.1 to $14.9 \mathrm{M} .{ }^{15}$ Nitrite in both cases is usually $2 \mathrm{M}$ or less. ${ }^{15}$ Therefore, the nitrited sodalite given in 
Table I should not form since it requires a nitrite molarity of 6 concurrent with sodium molarity of 6 or less. ${ }^{25}$ At higher sodium molarity germanium carbonates and sodium nitrite, which are soluble, were found to form. ${ }^{25}$

Since no thermodynamic data is available for the nitrated or hydroxy alumino-germanate sodalites no evaluation can be made as to whether their formation is favored over aluminosilicate sodalites or whether the formation kinetics for the germanate sodalites are the same or different than the aluminosilicates. However, from the known formation of the alumino-germanate sodalites from gels (see discussion above) and the known solubility of germanium species in caustic environments (see Section 2.2) which parallel the known formation and solubility of aluminosilicate sodalites, it is highly doubtful that the sodium-alumino-germanate sodalites would form in conditions where the alumino-silicate sodalites would not form.

Germanium as $\mathrm{GeO}_{4}^{-4}$ readily substitutes for $\mathrm{SiO}_{4}{ }^{-4}$ in various structures as the radius of Ge in IVfold coordination is $0.39 \AA$ while $\mathrm{Si}$ in IV-fold coordination is $0.26 \AA .{ }^{17}$ For example there is a complete solid solution between $\mathrm{Al}_{6} \mathrm{Si}_{2} \mathrm{O}_{13}$ and $\mathrm{Al}_{6} \mathrm{Ge}_{2} \mathrm{O}_{13}$ written as $\mathrm{Al}_{6}(\mathrm{Si}, \mathrm{Ge})_{2} \mathrm{O}_{13}{ }^{18}$ However given the low concentrations (ppm) of germanium and the high sodium molarity in the evaporator, Ge would substitute for only a small portion of the Si in a mixed sodium-aluminosilicate-germante sodalite. This small amount of substitution should be of no consequence to the $2 \mathrm{H}$ evaporator or the tank farm. 
Table I. Structurally Related Zeolite-A, Sodalite,and Cancrinite Group Phases

\begin{tabular}{|c|c|c|c|}
\hline $\begin{array}{c}\text { Substitution In Cage } \\
\text { Structure }\end{array}$ & Chemical Formula & $\begin{array}{l}\text { Common or } \\
\text { Mineral Name }\end{array}$ & Ref. \\
\hline \multicolumn{4}{|l|}{ AluminoSilicate Sodalites } \\
\hline $2 \mathrm{NaCl}$ & $\mathrm{Na}_{6}\left[\mathrm{Al}_{6} \mathrm{Si}_{6} \mathrm{O}_{24}\right](2 \mathrm{NaCl})$ & Sodalite & 19 \\
\hline $2 \mathrm{NaOH}$ & $\mathrm{Na}_{6}\left[\mathrm{Al}_{6} \mathrm{Si}_{6} \mathrm{O}_{24}\right](2 \mathrm{NaOH}) \bullet 1.5 \mathrm{H}_{2} \mathrm{O}$ & $\begin{array}{l}\text { Basic Sodalite or } \\
\text { Hydroxysodalite }\end{array}$ & 20 \\
\hline $2 \mathrm{NaNO}_{3}$ & $\mathrm{Na}_{6}\left[\mathrm{Al}_{6} \mathrm{Si}_{6} \mathrm{O}_{24}\right]\left(2 \mathrm{NaNO}_{3}\right)$ & Nitrated Sodalite & $\begin{array}{l}\text { PDF } \\
\# 50- \\
0248 \\
\end{array}$ \\
\hline $\mathrm{Na}_{2} \mathrm{SO}_{4}$ & $\mathrm{Na}_{6}\left[\mathrm{Al}_{6} \mathrm{Si}_{6} \mathrm{O}_{24}\right]\left(\mathrm{Na}_{2} \mathrm{SO}_{4}\right)$ & Nosean & 21 \\
\hline $\mathrm{xNaOH}+\mathrm{y} \mathrm{H} \mathrm{H}_{2} \mathrm{O}$ & $\mathrm{Na}_{6}\left[\mathrm{Al}_{6} \mathrm{Si}_{6} \mathrm{O}_{24}\right](\mathrm{xNaOH}) \bullet y \mathrm{H}_{2} \mathrm{O}$ & Basic Nosean & 16 \\
\hline $1-2(\mathrm{Ca}, \mathrm{Na}) \mathrm{SO}_{4}$ & $(\mathrm{Na})_{6}\left[\mathrm{Al}_{6} \mathrm{Si}_{6} \mathrm{O}_{24}\right]\left((\mathrm{Ca}, \mathrm{Na}) \mathrm{SO}_{4}\right)_{1-2}{ }^{\mathrm{t}}$ & Hauyne & 21 \\
\hline $\mathrm{x}(\mathrm{Ca}, \mathrm{Na})\left(\mathrm{S}, \mathrm{SO}_{4}, \mathrm{Cl}\right)$ & $\begin{array}{c}(\mathrm{Ca}, \mathrm{Na})_{6}\left[\mathrm{Al}_{6} \mathrm{Si}_{6} \mathrm{O}_{24}\right]((\mathrm{Ca}, \mathrm{Na}) \mathrm{S}, \mathrm{SO} \\
\left.{ }_{4}, \mathrm{Cl}\right)_{\mathrm{x}}{ }^{\mathrm{t}}\end{array}$ & Lazurite & $\begin{array}{c}\text { PDF } \\
\# 17-749\end{array}$ \\
\hline \multicolumn{4}{|c|}{ AluminoGermanate Sodalites } \\
\hline $\begin{array}{c}2 \mathrm{NaCl} \\
2 \mathrm{NaBr} \\
2 \mathrm{NaI} \\
\end{array}$ & $\begin{array}{c}\mathrm{Na}_{6}\left[\mathrm{AlGeO}_{4}\right]_{6}(2 \mathrm{NaCl}, 2 \mathrm{NaI}, \\
2 \mathrm{NaBr})\end{array}$ & $\begin{array}{l}\text { Alumino- } \\
\text { Germanate } \\
\text { Sodalite } \\
\end{array}$ & 22 \\
\hline $2 \mathrm{NaOH}$ & $\mathrm{Na}_{6}\left[\mathrm{AlGeO}_{4}\right]_{6}(2 \mathrm{NaOH})$ & $\begin{array}{l}\text { Hydroxy } \\
\text { Germanate } \\
\text { Sodalite } \\
\end{array}$ & $\begin{array}{c}23,24 \\
\text { PDF } \\
\# 43-242 \\
\end{array}$ \\
\hline $2 \mathrm{NaNO}_{3}$ & $\mathrm{Na}_{6}\left[\mathrm{AlGeO}_{4}\right]_{6}\left(2 \mathrm{NaNO}_{3}\right)$ & $\begin{array}{l}\text { Nitrited } \\
\text { Germanate } \\
\text { Sodalite }\end{array}$ & $\begin{array}{c}\text { PDF } \\
\# 43-243\end{array}$ \\
\hline $2 \mathrm{NaNO}_{2}$ & $\mathrm{Na}_{6}\left[\mathrm{AlGeO}_{4}\right]_{6}\left(2 \mathrm{NaNO}_{2}\right)$ & $\begin{array}{c}\text { Nitrited } \\
\text { Germanate } \\
\text { Sodalite } \\
\end{array}$ & $\begin{array}{c}25 \\
\text { PDF } \\
\# 43-241 \\
\end{array}$ \\
\hline $2 \mathrm{NaBH}_{4}$ & $\mathrm{Na}_{6}\left[\mathrm{AlGeO}_{4}\right]_{6}\left(2 \mathrm{NaBH}_{4}\right)$ & $\begin{array}{c}\text { Tetrahydroborate } \\
\text { Germanate } \\
\text { Sodalite } \\
\end{array}$ & 26 \\
\hline
\end{tabular}

t PDF \#20-1087

\subsection{Precipitation of Germanium Solids in the Evaporator Storage or Feed Tanks}

Germanium can also complex with iron and form $\mathrm{NaFeGe}_{2} \mathrm{O}_{6}$ which is isostructural with $\mathrm{NaFeSi}_{2} \mathrm{O}_{6}$ (acmite). It is believed from the solubility data given in Section 2.2 that neither the sodium iron oxide or other known sodium germanates will form in the RCT or in the Evaporator Feed Tank but if they do they should precipitate into the sludge at the bottom of the feed tank. $\mathrm{GeO}_{2}$ vitrifies readily ${ }^{27}$ as a substitute for $\mathrm{Si}$ and should provide no additional difficulties for DWPF processing. 
SRNL-STI-2011-00389

Revision 0

\subsection{Conclusions}

The conclusions of this study are that the impacts of germanium at a level $<2$ ppm per year (1.834 $\mathrm{mg} / \mathrm{L}$ ) to the RCT and subsequently to Tanks $22,38,41$ or 43 and ultimately to the $2 \mathrm{H}$ evaporator are minimal as most sodium germanates are soluble in the high $\mathrm{pH}$ of the RCT, the evaporator storage tank (Tank 22), the evaporator feed tank (Tank 43), the evaporator drop tank (Tank 38), and the evaporator itself. If sodium-germanium-alumino-silicates or sodium-germaniumalumino-ferrates, or sodium alumino-germanates do form in the storage or feed tanks they would precipitate and become part of the sludge. $\mathrm{GeO}_{2}$ vitrifies readily which is why it is being used by the DWPF laboratory low temperature fusions.

The $<2$ ppm being fed to the evaporator via Tanks 22, 38, 41 or 43 will be further diluted by incoming feeds to those tanks. If during evaporation in the $2 \mathrm{H}$ evaporator sodium aluminosilicates (sodalites and cancrinites) form, any Ge in solution will likely substitute for some small amount of the $\mathrm{Si}$ in these structures and there should not be any significant additional precipitation of sodium-alumino-silicate-germanates than of sodium-alumino-silicates. This is based on the fact that both $\mathrm{Ge}$ and $\mathrm{Si}$ are of a similar atomic size in four-fold coordination in sodalites $(0.39 \AA$ for $\mathrm{Ge}$ and $0.26 \AA$ for $\mathrm{Si}),{ }^{17}$ both are soluble in high caustic, and the $\mathrm{Si}$ and $\mathrm{Ge}$ sodalites form by a similar mechanism from gels. There is no evidence that sodium-aluminogermanate gels and sodalites will form preferentially to sodium-alumino-silicate gels and sodalites. The most likely scenario would be to form gels and sodalites of mixed $\mathrm{Si}$ and Ge such as $\mathrm{Na}_{8} \mathrm{Al}_{6}(\mathrm{Si}, \mathrm{Ge})_{6} \mathrm{O}_{24}(\mathrm{OH})_{2}$ or $\mathrm{Na}_{8} \mathrm{Al}_{6}(\mathrm{Si}, \mathrm{Ge})_{6} \mathrm{O}_{24}\left(\mathrm{NO}_{3}\right)_{2}$.

\subsection{Recommendations}

It is confirmed that the DWPF's decision to add an upper bound of $1.834 \mathrm{ppm}$ Ge to Attachment 8.2 in the current revision of the DWPF Waste Compliance Plan (WCP) is acceptable. There are no downstream impacts of using the $\mathrm{Cs}_{2} \mathrm{CO}_{3}-\mathrm{GeO}_{2}$ dissolution in the DWPF laboratory. 


\subsection{References}

1. K.G. Brown and R.L. Postles “The DWPF Product Composition Control System at Savannah River: Statistical Process Control Algorithm,” Ceram. Trans., V. 23, 559-568 (1991).

2. C.M. Jantzen, and K.G. Brown, "Statistical Process Control of Glass Manufactured for the Disposal of Nuclear and Other Wastes,” Am. Ceramic Society Bulletin, 72, 55-59 (May, 1993).

3 A.R. Shafer, E.W. Harrison, and R.N. Mahannah, "Evaluation of Germanium (IV) Oxide as a New Chemical for SRAT Dissolution Method,” SRR-WSE-2011-00034 (March 15, 2011).

4 C.J. Coleman, T.B. Edwards, M.A. Jones, and D.R. Best, "Development of Improved Dissolution Method for Elemental Analysis of DWPF SRAT Samples,” SRNS-STI2009-00470, Rev. 0 (September 1, 2009).

5 T.L. Fellinger and N.E. Bibler, "Results for the DWPF Slurry Mix Evaporator Condensate Tank, Off-gas Condensate Tank, and Recycle Collection Tank Samples,” WSRC-TR-2004-00577 (December 21, 2004).

6 E.W. Harrison, "Waste Acceptance Criteria for Liquid Waste Transfers to the 241-F/H Tank Farms,” X-SD-G-00001, Rev. 30 (June 2011).

7 D.J. Martin, “F/H Effluent Treatment Project Waste Acceptance Criteria,” X-SD-H00009, Rev. 4 (February 2009).

8 J.E. Ray, "Waste Acceptance Criteria for Aqueous Waste Sent to the Z-Area Saltstone Production Facility,” X-SD-Z-00001, Rev. 10 (March 2011).

9 C. F. Baes, Jr., and R. E. Mesmer, The Hydrolysis of Cations, John Wiley \& Sons, New York, pp. 343-349 (1976).

10 K. H. Gayer and O. T. Zajicek, "The Solubility of Germanium (IV) Oxide in Aqueous NaOH Solutions at $25^{\circ}$ C,” J. Inorg. Nucl. Chem., 26, 951-954 (1964).

11 W. Pugh, "CCLX. - Germanium. Part V. The Hydrolysis of Sodium Germanate and the Dissociation Constants of Germanic Acid,” J. Chem. Soc., 1994-2001 (1929).

12 R. K. Iler, The Colloid Chemistry of Silica and Silicates, Cornell University Press, Ithaca, New York, p. 12 (1955).

13 C. L. Baker and R. L. Jue, “The System Sodium Metasilicate-Water from $90{ }^{\circ} \mathbf{C}$ to the Ice Point,” J. Phys. Chem., 42(2), 165-169 (1938).

14 C. L. Baker and L. R. Jui, "The System $\mathrm{Na}_{2} \mathrm{O}-\mathrm{SiO}_{2}-\mathrm{H}_{2} \mathrm{O}$ : Isotherms and $10{ }^{\circ} \mathrm{C}$ and $31^{\circ} \mathrm{C}$,” J. Phys. Chem., 54(3), 299-304 (1950). 
15 C.M. Jantzen, J.E. Laurinat, and K.G. Brown, “Thermodynamic Modeling of Deposition in Savannah River Site (SRS) Evaporators, Part I. The 2H and 2F Systems” WSRCTR-2000-00293, Rev. 1 (April 4, 2002).

16 R. M. Barrer, J. W. Baynham, F. W. Bultitude, and W. M. Meier, “Hydrothermal Chemistry of the Silicates. Part V23I, Low-Temperature Crystal Growth of Aluminosilicates, and of Some Gallium and Germanium Analogues,” 195-208 (1959).

17 R.D. Shannon, "Revised Effective Ionic Radii and Systematic Studies of Interatomic Distances in Halides and Chalcogenides,” Acta Crystallographica A32, 751-767 (1976).

19 W. A. Deer, R. A. Howie, and J. Zussman, “Rock-Forming Minerals, Vol IV,” John Wiley \& Sons, Inc., New York, 435pp. (1963).

R. M. Barrer, J. W. Baynham, F. W. Bultitude, and W. M. Meier, "Hydrothermal Chemistry of the Silicates. Part V23I, Low-Temperature Crystal Growth of Aluminosilicates, and of Some Gallium and Germanium Analogues,” 195-208 (1959).

21 E.S. Dana, “A Textbook of Mineralogy,” John Wiley \& Sons, Inc., New York, 851pp (1932).

22 M.E. Fleet, "Structures of Sodium Alumino-Germanate Sodalites $\left[\mathrm{Na}_{8}\left(\mathrm{Al}_{6} \mathbf{G e}_{6} \mathbf{O}_{24}\right) \mathbf{A}_{2}\right.$, A=Cl, Br, I],” Acta Crystallographica, C45, 843-847 (1989).

23 E. L. Belokoneva, L.N. Dem’yanets, T.G. Uvarova, and N.V. Belov, “Crystal Structure of Ge Sodalite $\mathbf{N a}_{8} \mathbf{A l}_{6} \mathbf{G e}_{6} \mathbf{O}_{24}(\mathbf{O H})_{2}$,” Soviet Phys. Crystallographica, 27(5), 597-8 (1982)

24 M. Wiebcke, P. Sieger, J. Felsche, G. Engelhardt, P. Behrens, and J. Schefer, "Sodium Aluminogermanate Hydroxosodalite Hydrate $\left(\mathrm{Na}_{6+\mathrm{x}}\left[\mathrm{Al}_{6} \mathrm{Ge}_{6} \mathrm{O}_{24}\right](\mathrm{OH})_{\mathrm{x}} \bullet \mathrm{nH}_{2} \mathrm{O}(\mathrm{x} \sim 1.6\right.$, n 2.0): Synthesis, Phase Transitions and Dynamical Disorder of the Hydrogen Dihydroxide Anion, $\mathrm{H}_{3} \mathrm{O}_{2}^{-}$, in the Cubic High Temperature Form," Zeitschrift für Anorganische und Allgemeine Chemie, , 619 (7),1321-1329 (1993).

25 Bachmann and J.-Ch. Buhl, “Crystallization, Characterization and Structure of Nitrite Aluminogermanate Sodalite $\mathrm{Na}_{9}\left[\mathrm{AlGeO}_{4}\right]_{6}\left(\mathrm{NO}_{2}\right)_{2}$," Microporous and Mesoporous Materials, 28, 35-47 (1999).

26 J-C. Buhl, T.M. Gesing, T. Hofs, C.H. Ruscher, "Synthesis and Crystal Structure of Gallosilicate and Aluminogermanate Tetrahydroborate Sodalites $\mathrm{Na}_{8}\left[\mathrm{GaSiO}_{4}\right]_{6}\left(\mathrm{BH}_{4}\right)_{2}$ and $\mathrm{Na}_{8}\left[\mathrm{AlGeO}_{4}\right]_{6}\left(\mathrm{BH}_{4}\right)_{2}$," J. Solid State Chemistry, 179, 3877-3882 (2006).

27 M.B. Volf, “Chemical Approach to Glass,” Glass Science and Technology, V. 7, Elsevier Science Publishing Co., Inc, New York, 594 pp (1984). 


\section{Distribution:}
A. B. Barnes, 999-W
D. A. Crowley, 773-43A
A. P. Fellinger, 773-41A
S. D. Fink, 773-A
B. J. Giddings, 786-5A
C. C. Herman, 999-W
S. L. Marra, 773-A
A. M. Murray, 773-A
F. M. Pennebaker, 773-42A
W. R. Wilmarth, 773-A
J. M. Bricker, 704-27S
T. L. Fellinger, 704-26S
J. M. Gillam, 766-H
B. A. Hamm, 766-H
E. W. Holtzscheiter, 704-15S
J. F. Iaukea, 704-30S
M. T. Keefer, 766-H
D. W. Mcilmoyle, 766-H
J. E. Occhipinti, 704-S
D. K. Peeler, 999-W
J. W. Ray, 704-S
H. B. Shah, 766-H
D. C. Sherburne, 704-S
A. V. Staub, 704-27S
M. E. Stone, 999-W
P. R. Jackson, DOE-SR, 703-46A
K. H. Subramanian, 766-H
C. E. Duffey, 704-61H
A. W. Wiggins, 704-60H
A.R. Shafer, 704-27S
E.W. Harrison, 704-60H
S.J. Hensel, 703-41A
J.M. Becnel, 703-41A 